\title{
Lerner's concept of developmental homeostasis and the problem of heterozygosity level in natural populations
}

\author{
G. Livshits and E. Kobyliansky
}

Department of Anatomy and Anthropology, Sackler Faculty of Medicine, Tel Aviv University, Ramat Aviv, Israel.

In recent years adherents of the neutral mutation hypothesis have conducted a variety of statistical tests concerning the applicability of their theory to data of biochemical genetic polymorphism in natural populations. From the other side, the involvement of natural selection as a main evolutionary force responsible for the observed levels of polymorphism and heterozygosity have also been proposed in numerous field studies and theoretical considerations. However, none of these hypotheses completely and satisfactorily explains the collected data. We believe that one of the main causes of the discrepancy in theories is that the variability at each locus is considered independently in both of the abovementioned approaches. Yet, it was suggested long ago, and now there is an increasing amount of evidence indicating cooperation between different loci which can influence the variability at each of them. Thus we think that the use of models considering the genome as a suit of independent genes is a priori expected to decrease the efficacy of the approximation.

In the present review we attempt to draw attention to findings of interdependence of the variability of different characters and its possible limiting action on the growth of genetic diversity in natural populations. We do not try to give a universal explanation for the processes acting in populations and determining levels of heterozygosity. However, to our mind, the solution of the discussed question requires consideration of genes in their interactions.

\section{INTRODUCTION}

The explanation of genetic polymorphism in natural populations is a controversial issue among proponents of the neutral theory of protein evolution as opposed to those who favour the selection hypothesis (for review, see Nei, 1984; Nevo et al., 1984). The neutral mutation hypothesis argues that the degree of heterozygosity $(H)$ at steady state is proportional to the effective population size $(N)$ and mutation rate per locus $(u)$ : $H=$ $1-[1 /(4 N u+1)]$ (Kimura and Crow, 1964). Yet the range of average heterozygosity per locus per individual among species which are numerically extremely different is surprisingly narrow, being $0.05-0.18$ for the overwhelming majority of species and only exceptionally 0.00-0.26 (Nevo, 1978; Nevo et al., 1984). To cite Lewontin (1974, p. 208): "Since there is no reason to suppose that mutation rate has been specially adjusted in evolution to be reciprocal of population size for higher organisms, we are required to believe that higher organisms including man, mouse, Drosophila and the horseshoe crab all have population sizes within a factor of 4 of each other". Existing electrophoretic evidence indicates that the heterozygosity of numerous investigated species are below the lowest theoretically expected level as derived from neutral theory models (Nei and Graur, 1984; Nevo, 1983a). Fig. 1, extracted from Soule's (1976) and Nei and Graur's (1984) reviews show that even for $u$ values of $10^{-7}$ and $10^{-9}$, the observed heterozygosity pattern for equilibrium populations of various animal species, markedly deviates from the neutralist model. Although in numerous and diverse animal species the heterozygosity level and the effective population size are highly correlated and this accounts for about half $\left(r^{2}=0.49\right.$, Soule, 1976 or $r^{2}=0.43$, Nei and Graur, 1984) of the variation of $H$, the slope of the observed regression line is strongly and significantly lower than expected (fig. 1).

The mean observed heterozygosites $(\bar{H})$ are very similar for extremely different human populations (Nei and Roychoudhury, 1974; Altukhov et al., 1981 $a$ ). Using the above-mentioned formula one can calculate the expected $\bar{H}$ in some human populations. Neel (1980) estimated that in 


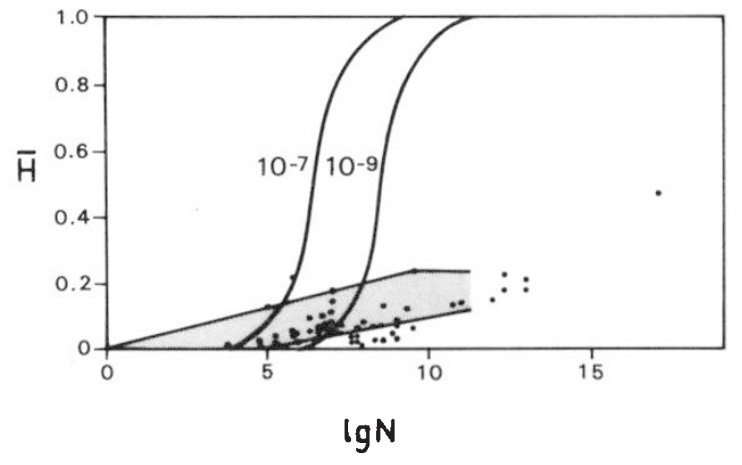

Figure 1 Expected (curves) and observed (points and shaded field) heterozygosites $(\bar{H})$ in various animal populations differing in population size $(N)$. The shaded field is from Soule's (1976) data; the points are from Nei and Graur's (1984) data. The first curve corresponds to the stepwise mutation model, assuming that the mutation rate is $10^{-7}$ locus/generation. The second curve represents the same model with a mutation rate of $10^{-9}$ locus/generation.

American Indian populations, mutations resulting in electrophoretic variants of a series of 28 blood proteins occur at a rate of $1.6 \times 10^{-5} /$ locus/ generation). Using a different approach for a Moscovite population, Altukhov (1980) obtained a similar value for the average mutation rate $(6 \times$ $10^{-5} /$ locus/generation). If we accept $\mathrm{Nei}$ and Graur's (1984) approach, that effective population size is not the size for a local population but for the entire species, then the heterozygosity level in Homo sapiens should be very near to 1 , i.e., much higher than the $H$ values obtained for any of the three major human races $(0 \cdot 099-0 \cdot 168)$ for different sets of enzymatic loci (Nei and Roychoudhury, 1974; Ryman et al., 1983). Thus the degree of heterozygosity and polymorphism in a natural population is significantly lower than that predicted by the neutral theory. Since heterozygous individuals are usually deemed more fit than homozygous ones, the heterozygosity level in the population should be higher than expected from the neutralistic model. It follows, then, that the observed heterozygosity is even less satisfactorily explained by a concept of heterozygote superiority.

The discrepancy between the predicted and the observed heterozygosity in natural populations is usually explained on the basis of the "recent bottleneck" hypothesis (Nei et al., 1975; Nei, 1984). This explanation seems to us very tenuous, and at least for several species it is entirely groundless (Soulé, 1976).

At the same time, in the cited studies, the variability of each locus was considered to be independent of other loci, thus not accounting for possible interactions between them. In the present paper, we will attempt to demonstrate the existence of such interdependence between different loci (characters) and its limiting influence on the population heterozygosity level. We will consider associations between loci (and characters) whose chromosome linkage is unknown.

\section{DATA AND DISCUSSION}

\section{Relationship between different sets of characters and heterozygote superiority}

Table 1 provides data on the relationship between heterozygosities at various biochemical loci and the variability of morphological and several other (non-biochemical) characters among such disparate life forms as plants, invertebrates and vertebrates, including humans. Although for some species a relationship was not found (we know of two such examples-see Hanford, 1980; McAndrew et al., 1982), for the majority of species and variables it was consistently demonstrated that an increase in the heterozygosity level leads to a decrease in the morphological variability. This is true, for instance, for such regular quantitative traits as height and weight, as well as for various estimates of fluctuating asymmetry (the level of the relationship in such cases can reach $r=$ $-0.961)$. One can see additionally that compared with homozygotes, heterozygous individuals were characterised by a higher rate of growth and survival and a more economical rate of oxygen consumption (table 1). These findings were applicable both at the individual and the population levels. In our study (Livshits and Kobyliansky, 1984) based on 250 young men sampled from a single population, we investigated the dependence of the variability of 48 anthropometric features on the degree of heterozygosity at four blood group loci. Of the traits studied, 19 showed a certain relationship, while six were independent. We found that the frequency of modal individuals (average \pm 0.67 S.D.) was highest in the group heterozygous at four loci, diminishing proportionately with decreasing heterozygosity levels (table 2). The degree of heterozygosity was also significantly inversely correlated with the coefficient of variation of the morphological characters albeit positively associated with the kurtosis values.

Multivariate analysis confirmed the results and showed that in multidimensional space heterozygotes tend to group near the center of a combined distribution of several independent traits (Koby- 
Table 1 Relationship between different sets of traits

\begin{tabular}{|c|c|c|c|c|}
\hline $\begin{array}{l}\text { Biochemical loci } \\
\text { heterozygotes }\end{array}$ & Morphological or other characters & Relationship & Species & Source \\
\hline $\begin{array}{l}* 4 \text {-Est loci of } \\
\text { endosperm }\end{array}$ & Embryonal survival & $\begin{array}{l}\text { Pos. } \\
\text { relationship }\end{array}$ & $\begin{array}{l}\text { Pinus sylvestris (L) } \\
\text { (Flora) }\end{array}$ & Pravdin et al., 1982 \\
\hline $\begin{array}{l}* * 21 \text { enzyme } \\
\text { loci }\end{array}$ & Mean annual basal area increment & $r=0.80-0.90$ & Pinus rigida (Flora) & Ledig et. al. 1983 \\
\hline $\begin{array}{l}{ }^{* *} \text { PGM1 and } 2 \text {, } \\
\text { GPI, LAP, HEX, MDH }\end{array}$ & $\begin{array}{l}\text { Fluctuating asymmetry = right-left } \\
\text { difference in number of plicae } \\
\text { on labial palps }\end{array}$ & $\begin{array}{l}r=-0.947 \\
r=-0.961\end{array}$ & $\begin{array}{l}\text { Elliptio complanata, } \\
\text { Lampsilis radiata } \\
\text { (Mollusca) }\end{array}$ & Kat, 1982 \\
\hline *LAP, GOT, GPI, PGM, & Weight (mean) growth & $\begin{array}{l}r=0.90 \\
r=-0.81\end{array}$ & Crassostrea virginica & $\begin{array}{l}\text { Singh and } \\
\text { Zouros, } 1981\end{array}$ \\
\hline *GPI, PGM, LAP, EST & Oxygen consumption rate & $r=-0.81$ & $\begin{array}{l}\text { Crassostrea virginica } \\
\text { (Mollusca) }\end{array}$ & $\begin{array}{l}\text { Koehn and } \\
\text { Shumway, } 1982\end{array}$ \\
\hline $\begin{array}{l}\text { GPI, PGM, LAP, } \\
\text { EST, STDH, PEP }\end{array}$ & Individual energy budgets & $\begin{array}{l}-0.25 \\
p<0.01\end{array}$ & $\begin{array}{l}\text { Mulinia lateralis } \\
\text { (Mollusca) }\end{array}$ & Garton et al., 1984 \\
\hline $\begin{array}{l}\text { *GPI, PGM, MPI, } \\
\text { NDH, GOT, MDH }\end{array}$ & $\begin{array}{l}V \text { of forewing length and diameter } \\
\text { of the forewing spot }\end{array}$ & $\begin{array}{l}\text { Neg. corr: } \\
\text { F-test }\end{array}$ & $\begin{array}{l}\text { Danaeus plexipus } \\
\text { (Insecta) }\end{array}$ & Eanes, 1978 \\
\hline *25 enzymatic & Fluctuating asymmetry of 8 & Neg. corr. & Poecilliopsis monacha & Vrijenhoek and \\
\hline locit & independent bilateral characters & $\begin{array}{l}\text { Friedman's } \\
x^{2}=12 \cdot 6\end{array}$ & (Pisces) & Lerman, 1982 \\
\hline $\begin{array}{l}\text { *EST, LDH, G6PDH, } \\
\text { PGM }\end{array}$ & $C V$ of meristic traits & $\begin{array}{l}\text { Neg. corr. } \\
\text { Sign test }\end{array}$ & $\begin{array}{l}\text { Fundulus heteroclitus } \\
\text { (Pisces) }\end{array}$ & Mitton, 1978 \\
\hline${ }^{* *}$ PGM, LDH, PX & Growth and sexual maturity rate & $\begin{array}{l}\text { Pos. } \\
\text { relationship } * * *\end{array}$ & $\begin{array}{l}\text { Onchorhynchus nerka } \\
\text { (Pisces) }\end{array}$ & $\begin{array}{l}\text { Altukhov and } \\
\text { Varnavskaya, } 1983\end{array}$ \\
\hline $\begin{array}{l}* * 42 \text { enzyme } \\
\text { loci }\end{array}$ & $\begin{array}{l}\text { Fluctuating asymmetry of five } \\
\text { meristic bilateral traits }\end{array}$ & $\begin{array}{l}r=-0.40 \\
r=-0.46\end{array}$ & $\begin{array}{l}\text { Salmo gairdneri } \\
\text { S. clarki (Pisces) }\end{array}$ & Leary et al., 1984 \\
\hline $\begin{array}{l}{ }^{*} \mathrm{LDH} 1 \text { and } 2, \text { PGM, } \\
\text { PHI, IDH, EST, PMI }\end{array}$ & Growth rate of body & $\begin{array}{l}\text { Kendall } \\
r=0.2-0.4 \\
p=0.05\end{array}$ & $\begin{array}{l}\text { Ambystoma tigrinum } \\
\text { (Amphibia) }\end{array}$ & $\begin{array}{l}\text { Pierce and } \\
\text { Mitton, } 1982\end{array}$ \\
\hline *8 enzyme loci $\dagger$ & $\begin{array}{l}\text { Fluctuating asymmetry of four } \\
\text { independent meristic bilateral traits }\end{array}$ & $r=-0.55$ & $\begin{array}{l}\text { Uta stansburiana } \\
\text { (Reptilia) }\end{array}$ & Soule, 1979 \\
\hline $\begin{array}{l}\text { Blood group loci: } \\
\text { MN, Ss, Cc (Rh } \\
\text { system), Duffy }\end{array}$ & $\begin{array}{l}C V \text { of Stature, Bi-trochanteric } \\
\text { diameter, Mesosternal chest } \\
\text { circumference, Interocular } \\
\text { diameter, Palm length }\end{array}$ & $\begin{aligned} r= & -0.78 \\
& -0.93\end{aligned}$ & $\begin{array}{l}\text { Homo sapiens } \\
\text { (Mammalia) }\end{array}$ & $\begin{array}{l}\text { Livshits and } \\
\text { Kobyliansky, 1984a }\end{array}$ \\
\hline
\end{tabular}

$\dagger$ List of studied enzymes not given in paper

* individual heterozygosity

** average population $H$

$* * *$ absence of statistical test

liansky and Livshits, 1985). Principal component analysis of 18 anthropometric variables in tri- and tetra-homozygous groups of individuals vs. tri- and tetra-heterozygous ones yielded the following findings:

(a) In 16 of the 18 traits the squared multiple correlation of each variable with all others and the squared multiple correlation (SMC) with the first five extracted factors ("communality") were higher in heterozygotes. The differences in SMC values reached 0.20 and 0.38 for such different and independent characters as palmar length and vertex-pronasale (one of the facial height indices), respectively.

(b) Mahalanobis distances of the factor scores for each individual from the whole population average were distinctly shorter in heterozygotes $\left(D_{\text {heterozygotes }}^{2}=0.950\right.$ vs. $D_{\text {homozygotes }}^{2}=$ 1.094). When the heterozygous and homozygous groups were considered separately, the former again showed an average $D^{2}$ that was smaller than in the latter $\left(D^{2}=1 \cdot 07\right.$ vs. $\left.1 \cdot 19\right)$. (c) The integration index of the correlation matrix (Cheverud et al., 1983), representing the generalised measure of the strength of correlations among all studied characters, was higher in heterozygotes- 0.74 vs. 0.63 .

These findings concur also with our analysis of the relationship between morphology and dermatoglyphic patterns (table 3), in which asymmetry and diversity of quantitative as well as discrete dermatoglyphic traits were significantly lower in morphologically tetra- and penta-modal (i.e., maximally heterozygous) individuals than in extreme ones. The mean values of the studied quantitative dermatoglyphic traits did not reveal any differences between multimodal and extreme groups, but their variability was clearly lower in the modal group (table 3 ).

Thus, our data, like the results of investigations carried out on taxonomically very different organims, point to a distinct correlation between heterozygosity levels of different sets of loci. What are the possible reasons for such an 
Table 2 Relationship between the heterozygosity and morphological variability of four blood group loci in a human population

\begin{tabular}{|c|c|c|c|c|c|c|c|}
\hline \multirow{2}{*}{$\begin{array}{l}\text { Parameter } \\
\text { of } \\
\text { distribution }\end{array}$} & \multirow[b]{2}{*}{0} & \multicolumn{4}{|c|}{ Degree of heterozygosity } & \multicolumn{2}{|c|}{$\begin{array}{l}\text { Statistical } \\
\text { treatment of } \\
\text { association }\end{array}$} \\
\hline & & 1 & 2 & 3 & 4 & $r$ & $p$ \\
\hline \multicolumn{8}{|c|}{ Height of body } \\
\hline$M$ & 0.368 & 0.365 & 0.597 & 0.538 & $0 \cdot 727$ & 0.91 & 0.03 \\
\hline$C V$ & $35 \cdot 6$ & $39 \cdot 8$ & $33 \cdot 5$ & $31 \cdot 3$ & $28 \cdot 3$ & -0.83 & $0 \cdot 08$ \\
\hline Kurtosis & $-1 \cdot 81$ & -1.47 & -0.47 & $0 \cdot 50$ & $1 \cdot 86$ & 0.98 & 0.01 \\
\hline$N$ & 19 & 52 & 77 & 39 & 11 & & \\
\hline \multicolumn{8}{|c|}{ Bi-trochanertic diameter } \\
\hline$M$ & $0 \cdot 278$ & 0.490 & 0.500 & 0.486 & 0.600 & $0 \cdot 86$ & 0.06 \\
\hline$C V$ & $42 \cdot 5$ & $36 \cdot 7$ & $37 \cdot 0$ & $38 \cdot 7$ & $33 \cdot 3$ & -0.78 & $0 \cdot 12$ \\
\hline Kurtosis & $-1 \cdot 73$ & $-1 \cdot 01$ & -0.95 & -0.87 & 0.08 & 0.92 & 0.03 \\
\hline$N$ & 18 & 51 & 78 & 37 & 10 & & \\
\hline \multicolumn{8}{|c|}{ Mesosternal chest circumference } \\
\hline$M$ & 0.421 & 0.483 & 0.500 & 0.564 & 0.727 & 0.94 & 0.02 \\
\hline$C V$ & $40 \cdot 1$ & $38 \cdot 9$ & $37 \cdot 5$ & $34 \cdot 6$ & $28 \cdot 3$ & -0.93 & $0 \cdot 02$ \\
\hline Kurtosis & -0.31 & -0.79 & $-0 \cdot 80$ & -0.60 & $1 \cdot 86$ & 0.64 & $0 \cdot 26$ \\
\hline$N$ & 19 & 54 & 78 & 39 & 11 & & \\
\hline \multicolumn{8}{|c|}{ Interocular diameter } \\
\hline$M$ & $0 \cdot 368$ & 0.547 & 0.410 & 0.579 & $0 \cdot 727$ & 0.94 & 0.02 \\
\hline$C V$ & $42 \cdot 7$ & $35 \cdot 1$ & $35 \cdot 8$ & $30 \cdot 8$ & $28 \cdot 3$ & -0.89 & 0.04 \\
\hline Kurtosis & $-1 \cdot 41$ & -0.73 & $-1 \cdot 23$ & -0.50 & $1 \cdot 86$ & 0.81 & 0.09 \\
\hline$N$ & 19 & 53 & 78 & 38 & 11 & & \\
\hline \multicolumn{8}{|c|}{ Chelion-chelion length } \\
\hline$M$ & 0.474 & 0.519 & 0.436 & 0.474 & $0 \cdot 727$ & 0.63 & 0.26 \\
\hline$C V$ & 38.9 & $36 \cdot 6$ & $36 \cdot 8$ & $34 \cdot 6$ & $27 \cdot 0$ & -0.93 & 0.02 \\
\hline Kurtosis & 0.038 & -0.844 & $-1 \cdot 216$ & -1.03 & 0.76 & $0 \cdot 24$ & $0 \cdot 25$ \\
\hline$N$ & 19 & 54 & 78 & 38 & 11 & & \\
\hline \multicolumn{8}{|c|}{ Palmar length } \\
\hline$M$ & $0 \cdot 333$ & 0.500 & 0.500 & 0.590 & 0.800 & 0.95 & 0.01 \\
\hline$C V$ & $39 \cdot 4$ & $35 \cdot 3$ & $36 \cdot 6$ & $31 \cdot 5$ & $23 \cdot 6$ & -0.92 & 0.03 \\
\hline Kurtosis & -1.52 & -0.98 & -0.96 & $-0 \cdot 46$ & $4 \cdot 50$ & $0 \cdot 80$ & 0.09 \\
\hline$N$ & 18 & 54 & 78 & 39 & 10 & & \\
\hline
\end{tabular}

$M$-Frequency of modal individuals (average \pm 0.67 S.D.)

$C V$-Coefficient of variation

$N$-Sample size

interdependence? When such correlation is revealed in comparisons of several conspecific populations having a common origin and differing in the levels of inbreeding, it is evidently attributable to the convergent influence of inbreeding on the various loci (Kobyliansky and Livshits, 1983). However, when heterozygous and homozygous individuals (for a few loci) from a single panmictic population are compared, inbreeding is insufficient to explain the relationship. Better then to turn to Lerner's (1954) concept of developmental homeostasis and his suggestion that phenotypic variability is inversely correlated with the level of heterozygosity. Shapiro (1970) suggested that developmental paths represent the outcome of coadapted genetic systems which have evolved because they produce phenotypes selected over time. Polygenic systems may buffer the developmental process against environmental insults, whereas deleterious genes may reduce the buffering below a threshold level. This view is supported by analysis of individuals with congenital anomalies, like cleft palate and cleft lip, which have shown that there is an increase in fingerprint asymmetry not only in affected individuals but also in their relatives (Woolf and Gianas, 1976; 1977). In agreement with these findings are the observations that persons with different genetic disorders (such as Down's syndrome and cleft palate) have significantly increased dental asymmetry (Sofaer, 1979; Barden, 1980). Recently Malina and Buschang (1984) found that mentally retarded individuals show significantly greater anthropometric asymmetry than normal individuals. That the fluctuating asymmetry is apparently a good indicator of overall develop- 
Table 3 Dermatoglyphic pattern differences between morphologically multimodal and multiextremal individuals. For comparison purposes we chose from our sample only individuals who were modal or extremal for five, or at least four, independent traits. The studied traits are given in table 2

\begin{tabular}{|c|c|c|c|}
\hline Dermatoglyphic pattern & $\begin{array}{l}\text { Multimodal } \\
\text { ind. }(N=74)\end{array}$ & & $\begin{array}{l}\text { Multiextreme } \\
\text { nd. }(N=63)\end{array}$ \\
\hline Asymmetry & \multirow[t]{2}{*}{$7 \cdot 80 \pm 0 \cdot 50$} & \multirow[t]{2}{*}{$<$} & \multirow[t]{2}{*}{$9.43 \pm 0.55$} \\
\hline$=\sqrt{\sum_{i=1}^{5}(\mathrm{Ri}-\mathrm{Li})^{2}}$ & & & \\
\hline $\begin{array}{l}\text { Asymmetry } \\
=(\Delta L-\Delta R)^{2}\end{array}$ & $26 \cdot 00 \pm 6 \cdot 42$ & $<$ & $43 \cdot 51 \pm 8 \cdot 59$ \\
\hline $\begin{array}{l}\text { Asymmetry } \\
=\left(S_{L}-S_{R}\right)^{2} / 100\end{array}$ & $58 \cdot 83 \pm 169 \cdot 5$ & \multicolumn{2}{|c|}{$<146.90 \pm 455.4$} \\
\hline $\begin{array}{l}\text { Asymmetry } \\
=\left(Q_{L}-Q_{R}\right)^{2}\end{array}$ & $117 \cdot 5 \pm 24 \cdot 78$ & $>$ & $106 \cdot 0 \pm 24 \cdot 29$ \\
\hline TRC-diversity & \multirow[t]{2}{*}{$6.84 \pm 0.45$} & \multirow[t]{2}{*}{$<$} & \multirow[t]{2}{*}{$7 \cdot 06 \pm 0.43$} \\
\hline$=\sqrt{\left(\sum_{i=1}^{5} K_{i}^{2}-Q T^{2} / 5\right)}$ & & & \\
\hline Shanon diversity & $0.61 \pm 0.03$ & $<$ & $0.66 \pm 0.03$ \\
\hline$C V$ of URC on D1 & $16 \cdot 1$ & $<$ & $21 \cdot 7^{*}$ \\
\hline$C V$ of URC on D4 & $26 \cdot 3$ & $<$ & $34 \cdot 8^{*}$ \\
\hline$C V$ of RRC on D1 & $34 \cdot 1$ & $<$ & $39 \cdot 5^{*}$ \\
\hline$C V$ of $\mathrm{RRC}$ on $\mathrm{D} 4$ & $32 \cdot 3$ & $<$ & $46 \cdot 5^{*}$ \\
\hline
\end{tabular}

Here $\mathrm{Ri}-\mathrm{Li}$ is the difference in ridge counts ( $\mathrm{RC}$ ) between the homologous fingers on the right $(\mathrm{Ri})$ and left $(\mathrm{Li})$ hands. $\Delta \mathrm{L}$ and $\Delta \mathbf{R}=$ maximal finger ridge count $(\max F R C)-\min F R C$ on the left and right hands, respectively. $S_{L}$ and $S_{R}$ are $\sum_{i=1}^{s} q_{i}^{2}-$ $Q^{2} / 5$ where $q i$ is FRC and $Q$ is total RC for left or right hands, respectively. $\mathrm{Ki}$ is the sum of the $\mathrm{RC}$ of the $i$ th pair of homologous fingers and $Q T$ is the total $\mathrm{RC}$ on both hands. The Shanon diversity is the information $=-\sum \mathrm{Pi} \ln \mathrm{Pi}$, where $P i$ is the frequency of loops (or whorls or arches) on the 10 fingers of each individual. URC and RRC are ulnar and radial ridge counts, respectively, on digit 1 (D1) and digit 4 (D4)

* Statistically significant difference $(p<0.05)$

mental stability is supported also by findings on non-human organisms (e.g., Leary et al., 1984, have noted that in fish deformed individuals were more asymmetric at five independent bilateral characters).

Ledig et al. (1983) suggested that the established negative correlation between heterozygosity at some loci and variability at others may be explained by the fact that the measured heterozygosity is simply a reflection of the general heterozygosity of the genome. Therefore, individuals homozygous for the sampled loci suffer from inbreeding depression. Mitton and Pierce (1980) simulated a correlation between the level of genomic heterozygosity of 100 polymorphic loci and that estimated from subsets of sampled loci. Their estimations seem to be rather insensitive to the heterozygosity of the whole data set and to the distribution of heterozygosity across loci. An algebraic approach to this issue by Chakraborty (1981) provided a similar analytical solution. This author has shown also that the correlation between sampled average heterozygosity and genomic average heterozygosity in a random individual decreases as the average heterozygosity in the population increases, although the absolute value of the correlation is largely dictated by the proportion of loci sampled from the genome. Thus the suggestions that the measured heterozygosity may merely reflect generalised genomic heterozygosity, and that the sampled highly homozygous genotypes represent more inbred individuals, are tenuous.

Soulé (1982) proposed a hypothesis that could explain some aspects of Lerner's developmental homeostasis in terms of the random events that occur during growth and development. On the basis of Lande's (1977) analysis, which compared homologous structures differing in the number of similar components and proved that variation of the character is negatively dependent on the number of components involved, Soule (1982, p. 762) argued that "homozygotes should occur with greater frequency in the tails of phenotypic distributions, while heterozygotes should occur near the mean with increasing frequency". The corollary of this theory is that variability increases and buffering of homozygote ontogenesis decreases as a reaction to the accidental perturbations and insults that occur in the course of development.

If we accept that a breakdown in developmental homeostasis is a pathological expression of genetic characters, then we can expect an increased frequency of pathology in homozygotes and extreme phenotypic variants. Indeed, Ford and Bull (cited by Soulé and Cuzin-Roudy, 1982) had already in 1926 examined 7000 herring skeletons for vertebral fusions and found the incidence of these abnormalities to be much greater in fish with either low or high number of vertebrae. Comparison of data on congenital malformations in Japanese infants with the available information on Caucasian and Negro populations, has shown that the biological impact of congenital malformations is very similar for all populations (Neel, 1958). Since more such children exhibit multiple major defects that would be expected on the basis of the individual frequencies of these defects, Neel concluded that a significant part of human congenital defects are segregants (phenodeviants) resulting from the existence and functioning of complex genetic homeostatic systems. A U-shaped mortality curve associated with birth weight and showing correlation of mortality with prematurity of infants was described by Terrenato et al. 
(1981 $a, b)$ and Ulizzi et al. (1981). A similar observation was made by Altukhov and co-workers (Altukhov, 1980; Botviniev et al., 1980; Altukhov et al., 1981b). These investigators reported that morphologically average newborns and infants (by stature and weight) are characterised by a significantly low frequency of diverse diseases (e.g. pneumonia, congenital malformations). An additional finding of these investigators was that sick children (e.g., with pneumonia) display lower levels of average biochemical heterozygosity (loci PGM, ACPH, MNSs, Rh) per locus, and a higher frequency of rare antigen combinations as well as rare electrophoretic protein variants than do healthy children. The considered correlations clearly point to stabilising selection as the most suitable factor for controlling the level of developmental homeostasis. Confirmation of this has been obtained both from empirical observations as well as from theoretical consideratios of the problem. As an example, we note that in different human communities the progress made in health care has led to reduction of both the stabilising effect and the intensity of selection (Terrenato et al., 1981b; Terrenato, 1983). Wright (1969) introduced an optimum selection model in order to examine situations in which an intermediate phenotypic value shows maximum fitness. According to this model the fitness decreases as the squared deviation of the phenotype from the optimum phenotype. Recent mathematical analyses of the relationship between fitness and the multiple-locus genetic state of an individual have also shown that individual fitness should increase with heterozygosity. It was found both analytically (Smouse and Ledig, 1984) and by simulation methods (Turelli and Ginzburg, 1983) that when using a set of two and/or multipleallele loci both in the multiplicative overdominance model as well as in the additive overdominance model, the average fitness monotonically decreases with the number of homozygous loci, but increases with heterozygosity at stable multilocus polymorphisms.

\section{Limits of heterozygote superiority}

Nevo $(1983 a, b ; 1984)$ collected a vast amount of data on biochemical polymorphism and heterozygosity $(H)$ in over 1100 plant and animal species and their dependence on various ecological, demographic and life history parameters. The parallel genetic patterns observed for many different species and the significant correlations between heterozygosity and polymorphism with some variables and their combinations, together with the findings on heterozygote advantages (partly presented in the first section of this review) all unequivocally suggest that selection is highly involved in genetic differentiation of populations and that random factors are unlikely to be prime movers of genetic differentiation in most species studied in the cited review (Nevo et al., 1984). Nevertheless, as has already been noted, heterozygosity and also the level of polymorphism for enzymatic loci are clearly below the lowest levels predicted by the random events model or by the heterotic model (fig. 1).

Presumably this is attributable to the fact that the heterozygosity is fairly well delimited and any increase in it is accompanied by the aforementioned heterotic effects. However, when these limits are exceeded there is a breakdown of developmental homeostasis and a general decrease in fitness. This hypothesis is illustrated in fig. 2 adapted from Vrijenhoek and Lerman (1982). The horizontal axis represents individual heterozygosity, reaching an optimum "Op" in a panmicitic population. On the vertical axis, representing the degree of developmental homeostatis, the corresponding point in $\mathbf{M}$ (maximal level). From point $\mathrm{Op}$, on the abscissa, heterozygosity can increase by means of interpopulation and interspecies hybridisation. The latter may lead to a general incompatibility between gene complexes coadapted within each population or species, resulting in a breakdown of developmental homeostasis. The numerous examples of sterility and multiple congenital anomalies of hybrids are well documented (Grant, 1963). A strong disturbance of development can be related not only to chromosomal imbalance, but also to differences in one or several loci as was established in old classical studies on maize (Beadle, 1930; 1933) and Drosophila

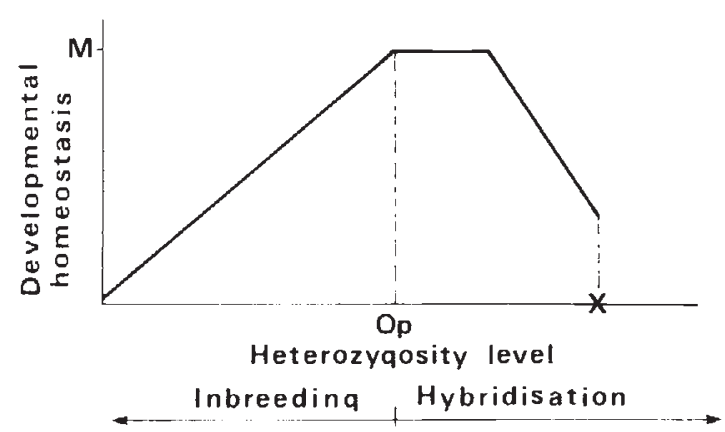

Figure 2 Scheme of the relationship between the degree of developmental homeostasis and the individual level of heterozygosity. $X$ reflects the different species hybridisation. 
(Gowen, 1931). A disparity between nuclear and cytoplasmic genes can also be considered a cause of the hybridisation disadvantage (Markert and Ursprung, 1971). If speciation occurs by a gradual accumulation of differences (irrespective of whether by point mutations or by duplications) then we should expect deviation from the norm already in populations intermixing within a species. It is reasonable to assume that this deviation will be related to the measure of differentaition and level of isolation prior to intermixing. For instance, in children from intermarriages in human populations temporally and geographically isolated, a slower rate of development of some morphological traits was observed (Nikityuk and Filippov, 1975) as well as an increase in the frequency of several congenital anomalies (Altukhov, 1980).

A decrease in the heterozygosity level in a population from point $\mathrm{Op}$ (on axis $\mathrm{X}$ ) represents inbreeding. The negative influence of inbreeding depression on animal and human development is well known. However, there are several additional facts supporting the idea that the individual and intrapopulational levels of heterozygosity and polymorphism are well delimited. These levels seem to be a result of opposing forces operating on the individual and the population, namely, (1) the advantage of heterozygotes under normal conditions and the possible neutrality of some alleles; and (2) the disadvantage of heterozygotes in extreme environments, segregation load and the possible disharmonisation of genotype and phenotype by a high level of combination originating from high intra- and inter-locus diversity. The advantage of heterozygotes has already been considered here. As for the disadvantage this deserves discussion at some length. To begin with, any expected genetic diversity is decreased by the destructive action of the majority of new mutations, which must be eliminated from populations. Altukhov et al. (1983) estimated the spontaneous mutation rate in the pine tree to the $1.9 \times$ $10^{-4}$ locus/generation in early embryonal stages and showed that negative selection pressure at the seedling stage can reach 100 per cent. Various epidemiological studies of human populations have given extremely high estimates of the number of genetic diseases. According to Matsunaga's (1982) review, about 5 per cent of all live-born children in Northern Ireland suffer from a serious non-chromosomal genetic disease. Similarly, data available to him from British Columbia indicated that the frequency of afflicted children among 756,304 live births over 21 births reached 4.05 per cent. Vogel (1984) pointed out that, even excluding multiple heterozygotes for 114 recessive diseases (occurring practically in each population and with each disease having a homozygote frequency of $10^{-7}$ ), approximately 31 per cent of the population of the state was heterozygous for one of the 114 metabolic diseases mentioned. In reality (and based on McKusik, 1983), Vogel supposed that in each population each individual might be heterozygous for one or several recessive genes with deleterious effects in homozygotes. Obviously, these genes form an enormous genetic load, held in the population by a balance between selection and recurrent mutation. In each generation the divergence from the expected rate of mutation at a given locus will be reduced by the affection probability (Morton, 1982):

$$
\begin{aligned}
\boldsymbol{S} & =\boldsymbol{e}-\left\{\left[\sum x+\sum q^{2} s+2 \sum q(1-q) . s h\right]\right. \\
& \left.+\left[\sum q s-q^{2} s-2 \sum q(1-q) s h\right] F\right\},
\end{aligned}
$$

where the outer brackets contain the so-called panmictic load, and the inner brackets-the inbred load, $x$ is the probabilty of a particular environmental cause of affection, $s$ and $s h$ are the coefficients of selection against homozygotes and heterozygotes, respectively, and $F$ is the coefficient of inbreeding.

It is evident that as the functional importance of the locus-trait increases, the affection probability also increases, so that at some loci monomorphism can be expected and therefore, a priori, the heterozygosity and polymorphism levels must be lower than predicted from the neutral model. Based on this reasoning and on observational data, Altukhov $(1974,1982)$ postulated the duality of the structural-functional organisation of the eucaryotic genome. This concept regards the polymoprhism of proteins as a relatively neutral variability related to the secondary adaptive properties of species, and sees the genetically monomorphic proteins as markers of functions so basic that variability normally is biologically intolerable. The differences between species, for polymorphic loci, are in principle similar to those between populations within species, i.e., they are differentiated by the frequency of the same allele or by particular alleles, specific only for them. At monomorphic loci the differences between species are qualitative, i.e., the species are discrete and are made unique by these characters as are different genotypes within species. Carson (1975) formulated a concept closely resembling the described hypotheses. He considered two systems of genetic variability- 
"open" and "closed"- the first representing polymorphic loci, which slightly influence individual fitness, while the second is stable, with only interspecific differences.

The expectation that polymorphism should be restricted to only part of the genome is in agreement with the principle of "polymorphism generating more polymorphism" which advocates that new mutations are more likely to occur at heterozygous that at homozygous loci (Ohno, 1970). Indeed, a high correlation $(r=0.7-0.9)$ was observed in some organisms between the frequency of new mutations and rare alleles on the one hand, and the "old" polymorphism level at a particular locus on the other (Koehn and Eanes, 1976; Altukhov et al., 1983).

Moreover, the existing heterozygosity is perhaps also controlled by selection since, as stated by Vogel (1984, p. 410), "heterozygotes have, as a rule, about 50 per cent of the normal enzyme activity", which "being sufficient under normal living conditions, might very often lead to a relative deficiency of a normal metabolite or to an unusual increase of an abnormal one, if the metabolic pathway is burdened by special external or internal conditins and influences".

\section{Interlocus interaction and genetic diversity level in populations}

The normal action and functioning of each organ, of physiological processes and the performance of an.organism as a whole, depend on harmonic cooperation between loci. In physico-chemical terms this means a conformity in the structure of the interacting gene products as well as in the concentration of these products. The majority of biochemical reactions in an organism, including all enzyme-catalysed processes, proceed through more than one step, so that the reaction kinetics do not depend only on initial reactants and final products. The final step depends on the slowest stage which can occur in any sequence of the general chain of reactions (the "rate controlling step"). Thus the optimal interaction is dictated by the qualitative and quantitative conformity between various non-allelic gene products.

The number of all possible combinations (without transpositions) formed from $n$ alleles at $m$ loci is $N=\left[(n+1)^{m} n^{m}\right] / 2^{m}$, which means that there is a progressive increase in $N$, proportional to the number of alleles in the $m$ th degree. Such genetic diversity, augmented by Mendelian segregation of non-linked loci, should mean that the creation of the internally co-adapted genome will occur more slowly with an increasing level of polymorphism. As is well known, inversions and some other chromosomal aberrations may be mechanisms preventing segregation and, thereby, decreasing genetic diversity in panmictic populations (Dobzhansky, 1970).

Lewontin et al. (1978) considered the conditions necessary for a stable equilibrium at multiallelic loci and showed statistically that heterosis alone is not a mechanism for maintaining many alleles at a locus. Rather they found that even when all heterozygotes are more fit than homozygotes, the proportion of fitness arrays that will lead to a stable equilibrium of six or seven alleles is vanishingly small. If this finding is at least approximately applicable to multilocus models, then we should expect an even fewer number of alleles per locus than is predicted by the monolocus model. Indeed, Turelli and Ginzburg (1983), in their computrer simulation analysis of multilocus models, found that even for three unlinked diallelic loci with a polymorphism threshold of $10^{-3}$, only about 0.5 per cent of the random initial conditions and matrices produced stable three-locus polymorphism.

The conclusion of this study, as well as of Lewontin et al.'s (1978) theoretical paper, are in agreement with results obtained in field investigations of numerous and diverse organisms. In 20 randomly selected species of plants, invertebrates and vertebrates, shown in table 4 , about 92 per cent of the electrophoretically studied loci have been found to be mono- or diallelic.

There are other observation evidences supporting our hypothesis of selection limiting genetic variability and heterozygote level in populations: (a) Molecular evidence The analysis of molecular structure and genetic variation of enzymes showed a significant correlation between enzyme polymorphism and sub-unit molecular weight in such varied species as Drosophila and Homo sapiens (Brown and Langley, 1979; Koehn and Eanes, 1979).

Since mutations are errors introduced into the DNA or occurring at any stage of the cellular protein biosynthesis, one would assume that individual and populational heterozygosity is simply a function of the genome or of the protein values. However, this is not the case. Results of analysis of the variance of heterozygosity by gene and species showed significant effects due to both (Brown and Langley, 1979). Moreover, these investigators have also found that the heterozygosity of a certain gene may be more dependent on other gene effects than on its derivative protein. Com. 
Table 4 Frequency distribution of polymorphic gene level per population in different species (only electrophoretic analysis results are presented)

\begin{tabular}{|c|c|c|c|c|c|c|c|c|c|c|}
\hline No. & 1 & $2^{\text {Numt }}$ & 3 & $\begin{array}{l}\text { eles per } \\
4\end{array}$ & $\begin{array}{l}\text { locus } \\
5\end{array}$ & 6 & $7+$ & $\begin{array}{l}\text { Number } \\
\text { of } \\
\text { studied } \\
\text { loci }\end{array}$ & $\begin{array}{l}\text { Number } \\
\text { of } \\
\text { studied } \\
\text { populations }\end{array}$ & $\begin{array}{l}\text { Species and } \\
\text { Reference }\end{array}$ \\
\hline 1 & 0.705 & $0 \cdot 165$ & 0.096 & 0.024 & 0.004 & 0.006 & 0 & 28 & 28 & $\begin{array}{l}\text { Barley (Flora) } \\
\text { Nevo et al., } 1979\end{array}$ \\
\hline 2 & 0.861 & 0.092 & 0.047 & 0 & 0 & 0 & 0 & 13 & 8 & $\begin{array}{l}\text { Dismodium (Flora) } \\
\text { Schaal and Smith, } 1980\end{array}$ \\
\hline 3 & 0.650 & $0 \cdot 175$ & 0.125 & 0.025 & 0.025 & 0 & 0 & 20 & 2 & $\begin{array}{l}\text { Xerocrasse seetzenii (Mollusca) } \\
\text { Nevo et al., } 1981\end{array}$ \\
\hline 4 & 0.525 & 0.275 & $0 \cdot 125$ & 0.025 & 0.050 & 0 & 0 & 20 & 2 & $\begin{array}{l}X . \text { erkelii (Mollusca) } \\
\text { Nevo et al., } 1981\end{array}$ \\
\hline 5 & 0.758 & 0.232 & 0.010 & 0 & 0 & 0 & 0 & 22 & 9 & $\begin{array}{l}\text { Armadillidium vulgare (Crustacea) } \\
\text { Beck and Price, } 1981\end{array}$ \\
\hline 6 & 0.566 & 0.330 & 0.087 & 0.017 & 0 & 0 & 0 & 23 & 5 & $\begin{array}{l}\text { Gledia captiva (Insecta) } \\
\text { Moran et al., } 1980\end{array}$ \\
\hline 7 & $0 \cdot 320$ & 0.560 & $0 \cdot 040$ & 0.080 & 0 & 0 & 0 & 25 & 1 & $\begin{array}{l}\text { Drosophila melanogaster (Insecta) } \\
\text { Band, } 1975\end{array}$ \\
\hline 8 & 0.909 & 0.045 & 0.045 & 0 & 0 & 0 & 0 & 22 & 1 & $\begin{array}{l}\text { Sarotherodon andersoni (Pisces) } \\
\text { McAndrew and McJumdar, } 1983\end{array}$ \\
\hline 9 & 0.818 & 0.136 & 0.045 & 0 & 0 & 0 & 0 & 22 & 1 & $\begin{array}{l}\text { Sarotherodon jipe (Pisces) } \\
\text { McAndrew and McJumdar, } 1983\end{array}$ \\
\hline 10 & 0.536 & 0.407 & 0.056 & 0 & 0 & 0 & 0 & 25 & 20 & $\begin{array}{l}\text { Coregonus albula (Pisces) } \\
\text { Vuorinen et al., } 1981\end{array}$ \\
\hline 11 & 0.695 & $0 \cdot 233$ & 0.069 & 0.003 & 0 & 0 & 0 & 28 & 11 & $\begin{array}{l}\text { Frog (Amphibia) } \\
\text { Nevo and Yang, } 1982\end{array}$ \\
\hline 12 & 0.812 & $0 \cdot 158$ & 0.029 & 0 & 0 & 0 & 0 & 22 & 20 & $\begin{array}{l}\text { Lizard ( } 3 \text { species) (Reptilia) } \\
\text { Gorman et al., } 1975\end{array}$ \\
\hline 13 & 0.543 & 0.276 & $0 \cdot 108$ & 0.056 & 0.017 & 0 & 0 & 23 & 9 & $\begin{array}{l}\text { Peromyseus (Mammalia) } \\
\text { Loundenslager, } 1978\end{array}$ \\
\hline 14 & 0.555 & $0 \cdot 111$ & 0.333 & 0 & 0 & 0 & 0 & 18 & 1 & $\begin{array}{l}\text { Microtus (Mammalia) } \\
\text { Nygren and Rasmuson, } 1980\end{array}$ \\
\hline 15 & 0.907 & 0.093 & 0 & 0 & 0 & 0 & 0 & 23 & 18 & $\begin{array}{l}\text { Moose (Mammalia) } \\
\text { Ryman et al., } 1980\end{array}$ \\
\hline 16 & 0.729 & $0 \cdot 179$ & 0.079 & 0.013 & 0 & 0 & 0 & 14 & 10 & $\begin{array}{l}\text { Rat (Mammalia) } \\
\text { Beck et al., } 1981\end{array}$ \\
\hline 17 & 0.876 & 0.099 & 0.025 & 0 & 0 & 0 & 0 & 27 & 3 & $\begin{array}{l}\text { Gerbil (Mammalia) } \\
\text { Nevo, } 1982\end{array}$ \\
\hline 18 & $0 \cdot 545$ & $0 \cdot 364$ & 0.091 & 0 & 0 & 0 & 0 & 22 & 1 & $\begin{array}{l}\text { Homo sapiens (Mammalia) } \\
\text { Altukhov et al., } 1981 a\end{array}$ \\
\hline $\bar{X}$ & $0 \cdot 717$ & $0 \cdot 209$ & 0.060 & 0.011 & 0.003 & 0.001 & 0 & 23 & 150 & Average per population \\
\hline
\end{tabular}

parisons of intralocus heterozygosity carried out on proteins with different quaternary structure in numerous species ranging from humans to plants, have shown a strong negative correlation with monomeric proteins varying to a greater extent than dimers, and even more so when compared to trimers and tetramers (table 5). Koehn and Eanes (1979) noted that the mean heterozygosity per locus for enzymes with virtually identical average sub-unit molecular weight, decreases with increasing structural complexity. These investigators also compared the variability among the following three enzyme groups: (1) all monomeric enzymes, (2) single-locus multimeric enzymes + multilocus multimeric enzymes which do not form hybrid molecules, and (3) multilocus multimeric enzymes that form interlocus hybrids. They found that the third group exhibits a very low percentage of polymorphic loci.

Table 5 Relationship between heterozygosity and quaternary structure of various enzymatic and structural proteins

\begin{tabular}{llll}
\hline $\begin{array}{l}\text { Quaternary } \\
\text { structure }\end{array}$ & Man* & Plaice** $^{*}$ & Range*** $^{*}$ \\
\hline Monomers & 0.096 & $0 \cdot 164$ & $0 \cdot 113-0 \cdot 186$ \\
Dimers & 0.071 & $0 \cdot 132$ & $0 \cdot 040-0 \cdot 122$ \\
Tetramers & 0.050 & 0.057 & $0 \cdot 015-0.026$ \\
\hline
\end{tabular}

* Harris et al., 1977

** Ward and Bardmore, 1977

*** Range of averages for 23 invertebrate and 23 vertebrate species; Koehn and Eanes, 1979 
Pierce and Mitton (1980) similarly found a very strong and significant negative correlation between $H$ (and particularly $P$ ) and the total amount of nuclear DNA in various species of salamander. This finding is in line with Nevo's (1984) generalisation for numerous species, that genetic diversity ( $H$ and $P$ ) is higher in species with a smaller diploid chromosome number. Thus these data clearly indicate that where potential conditions exist for a high interlocus variability, the intralocus variability tends to be low.

(b) Organismic and taxonomic evidence Nevo and colleagues (1984) compared hundreds of species and thousands of populations from different taxa with respect to 21 biotic variables and reached the following conclusions: (1) The levels of genetic diversity vary non-randomly among populations, species and higher taxa; (2) Mean values of both polymorphism and heterozygosity decrease in the following order: Invertebrata $>$ Plants $>$ Vertebrata; (3) Among invertebrates, crustaceans and insects display the lowest values of $H$ and $P$. The vertebrates showing the lowest mean values of $H$ and $P$ were mammals; (4) All species, but especially mammals, present a distinct right skewness of the $H$ and $P$ distribution; (5) Genetic diversity is higher in species with small body size, in numerically large species with a patchy population structure and limited migration, and in solitary species.

From the first four conclusions it would seem that a decrease in diversity is related to an increase in the morpho-physiological level of a taxon and this, in our opinion, reflects the level of complexity of an organism, whose functioning demands maximal harmony between its interacting parts. The first clause of the fifth conclusion is also in agreement with this. As for the large-numbered species, they should have a large $N_{e}$ and therefore a high $H$ and $P$. From Nevo's review, however, it is clear that higher intralocus heterozygosity is to be encountered in solitary or slow-moving species. It would thus seem that the spatial subdivision of a population must decrease genetic combination in it and thereby counteract the growth of interlocus genetic variability. However, the intralocus diversity in this case can increase.

As we have attempted to point out, the creation of multiple internally coadapted heterozygous genotypes acts against the maintenance and preservation of such complex genotypes during free recombination as a result of cross-fertilisation. We therefore suggest instead either a relative neutralisation of differences between alleles or the existence of specific mechanisms preventing a re- combination in populations (species) with a high level of heterozygosity. Lande (1984), for example, investigated by mathematical modeling the conditions of maintaining the genetic correlations between two polygenic characters. He concluded that, even when selection favours a hgh genetic correlation between the characters, with random mating and no linkage between loci influencing different traits, the genetic correlation between characters is likely to be small in magnitude. A genetic correlation of large magnitude can be maintained only if the loci influencing different characters are tightly linked, or if there is a high level of inbreeding in the population. Because in parthenogenetic species fertilisation does not occur, e.g. they produce genetically highly inbred offspring, one would expect them to display a high level of heterozygosity. Indeed, the evidence indicates that these populations commonly possess elevated levels of heterozygosity in comparison with cross-fertilised populations of the same species (Saura et al., 1977; Lokki and Saura, 1980; Vrijenhoek and Lerman, 1982). In general, parthenogenetic species exhibit a significantly higher heterozygosity level than do primary outcrossing (i.e., sexual) species $(H=0.301$ vs. 0.069 ; $p<0.01$ ) (Nevo et al., 1984). The parthenogenetic species as a rule are polyploids, but even diploid parthenogenetic races have a higher $H$ than do bisexuals. For example, in the insect population of Polydrosus molis, Lokki et al. (1976) found $H$ to be equal to $0 \cdot 14$ and $0 \cdot 36$ for the bisexual and parthenogenetic elements, respectively.

\section{CONCLUSIONS}

1. There are numerous genetic data from such diverse taxonomic groups as plants, invertebrates and vertebrates, including humans, indicating that sets of loci interact. Such a relationship can be attributed to Lerner's concept of developmental homeostasis, which maintains that the higher the level of heterozygosity the greater the extent of the buffering against insults by the external and internal environment.

2. Situations exist in which there is a breakdown of developmental homeostasis and general decrease in the fitness. Such breakdown can be provoked by the intermixing of populations within a species as a consequence of general incompatibility between gene complexes coadapted within each population. 
3. Diversity-reducing selection restricts unlimited enhancement of heterozygosity $(H)$ and polymorphism $(P)$ in natural populations. Otherwise unchecked increase of $H$ and $P$ could lead to such a high combination rate within the genome that harmonic coordination and cooperation between different loci would become impossible.

Acknowledgements We are very grateful to Prof. 1. Ashkenazi of Tel Aviv University and to Prof. L. Ginzburg of State University of New York at Stony Brook for critically reading the original manuscript and offering many useful suggestions.

\section{REFERENCES}

ALTUKhov, YU. P. 1974. Population genetics of fish. Pishchevaya promyshlenost, Moscow (In Russian) (English translation, Fisheries and Marine Service Transl. Ser. No. $3548,1975)$.

ALTUKHOV, YU. P. 1980. Environmental conditions and genetic monitoring of populations. In Proceedings of the XIV International Congress of Genetics. Vol. 1, book 1 (ed M. E. Vartanian), Mir Publishers, Moscow, pp 238-256.

ALTUKHOV, YU. P. 1982. Biochemical population genetics and speciation. Evol, 36, 1168-1181.

ALTUKHOV, YU. P., CHILCHEVSKAYA, R. I. AND SHURKHAL, A. V. $1981 a$. Levels of polymorphisms and heterozygosity of Russian population of Moscow: Data on 22 loci specifying blood proteins. Genetika (USSR), 17, 546-554.

ALTUKHOV, YU. P., KURBATOVA, O. L., BOTVINIEV, O. K., AFANASIEV, K. K., MALININA, T. V., KHOLAD, O. N., STRELKOVA, L. K. AND IVANOVA, V. S. $1981 b$. Gene markers and diseases: genetic, anthropometric and clinical characteristics of children with acute pneumonia. Genetika (USSR), 17, 920-931.

ALTUKHOV, YU. P., DUKHAREV, V. A. AND ZHIVOTOVSKY, L. A. 1983. Spontaneous mutation rate in populations under selection pressure against rare protein variants. Genetika (USSR), 19, 264-276.

ALTUKhov, YU. P. AND VARnAVSKAyA, N. V. 1983. Adaptive genetic structure and its connection with intrapopulation differentiation for sex, age and growth rate in sockeye salmon, Oncorhynchus nevka (Walb). Genetika (USSR), $19,796-807$.

BAND, H. T. 1975. A survey of isozyme polymorphism in Drosophila melanogaster natural population. Genetics, 80 , 761-771.

BARDEN, H. S. 1980. Fluctuating dental asymmetry: A measure of developmental instability in Down Syndrome. Am. J. Ph. Anthr., 52, 169-173.

BECK, M. L., KENNEDY, M. L. AND BIGGERS, C. J. 1981. Genetic variation in Ord's Kangaroo rat Dipodomys ordii in Oklahoma. Am. Midland Nat., 105, 77-83.

BECK, M. L. AND PRICE, J. O. 1981. Genetic variation in the terrestrial isopod, Armadillidium vulgare. J. Heredity, 72, $15-18$.

BEADLE, G. W. 1930. Genetical and cytological studies of Mendelian asynapsis in Zea mays. Cornell. Univ. Agr. Exp. St., 129.

BEADLE, G. W. 1933. Further studies of asynaptic maize. Cytologia, 3.
BotVinieV, O. K., KURBATOVA, O. L. AND ALTUKHOV, YU. P. 1980. Population genetic approach to the problem of nonspecific biological resistance of human organism. Genetika (USSR), 16, 1884-1894.

BROWN, A. J. L. AND LANGLEY, C. H. 1979. Correlation between heterozygosity and subunit molecular weight. Nature, 277, 649-651.

CARSON, H. 1975. The genetics of speciation at the diploid level. Am. Natur., 109, 83-92.

CHAKRABORTY, R. 1981. The distribution of the number of heterozygous loci in an individual in natural populations. Genetics, 98, 461-466.

CHEVERUD, J. M., RUTLEDGE, J. J. AND ATCHLEY, W. R. 1983. Quantitative genetics of development: genetic correlations among age-specific trait values and the evolution of ontogeny. Evol., 37, 895-905.

DOBZHANS KY, T. 1970. Genetics of evolutionary process. Columbia Univ. Press.

EANES, W. F. 1978. Morphological variance and enzyme heterozygosity in the Monarch Butterfly. Nature, 276, $263-$ 264.

GARTON, D. W., KOEHN, R. K. AND SCOTT, T. M. 1984. Multiplelocus heterozygosity and the physiological energetics of growth in the coot clam Mulinia lateralis from a natural population. Genetics, 108, 445-455.

GORMAN, G. C., SOULE, M., YANG, S. Y. AND NEVO, E. 1975 Evolutionary genetics of insular Adriatic lizards. Evol., 29, 52-71.

GOWEN, J. W. 1931. Genetics of non-disfunctional forms in Drosophila. Am. Natur., 65.

GRANT, v. 1963. The origin of adptations. Columbia Univ. Press. HANDFORD, P. 1980. Heterozygosity at enzyme loci and morphological variation. Nature, 286, 261-262.

HARRIS, H., HOPKINSON, D. A. AND EDWARDS, Y. H. 1977. Polymorphism and subunit structure of enzymes: A contribution to the neutralist-selectionist controversy. Proc. Natl. Acad. Sci. USA, 74, 698-701.

KAT, P. W. 1982. The relationship between heterozygosity for enzyme loci and developmental homeostasis in peripheral populations of aquatic bivalves (Unionidae) Am. Natur. $119,824-831$.

KIMURA, M. AND CROW, J. F. 1964. The number of alleles that can be maintained in a finite population. Genetics, 49, 725-738.

KOBYLIANSKY, E. AND LivShits, G. 1985. Anthropometric multivariante structure and dermatoglyphic peculiarities in biochemically and morphologically different heterozygous groups. Am. J. Phys. Anthopol., (In press).

KOBYLIANSKY, E. AND LIVSHITS, G. 1983. Relationship between levels of biochemical heterozygosity and morphological variability in human populations. Ann. Hum. Genet., 47, 215-223.

KOEHN, R. K. AND EANES, W. F. 1976. An analysis of allelic diversity in natural populations of Drosphila: The correlation of rare alleles with heterozygosity. In S. Karlin and E. Nevo (eds) "Population genetics and ecology" Academic Press, New York, 377-390.

KOEHN, R. K. AND EANES, W. F. 1979. Molecular structure, polypeptide size, and genetic variation of enzymes. Iso zymes: Current Topics in Biological and Medical Research, $3,185-211$.

KOEHN, R. K. AND SHUMWAY, S. E. 1982. A genetic/physiological explanation for differential growth rate among individuals of the American oyster, Crassostrea virginia (Gmelin). Marine Biol. Letters, 3, 35-42.

LANDE, R. 1977. On comparing coefficients of variation. Syst. Zool, , 26, 214-217 
LANIDE, R. 1984. The genetic correlation between characters maintained by selection, linkage and inbreeding. Genet. Res. Camb., 44, 309-320.

LEARY, R. F., ALLENDORF, F. W. ANI) KNUDSEN, K. L. 1984. Superior developmental stability of heterozygotes at enzyme loci in salmonid fishes. Am. Natur., 124, 540-551.

LERNER, I. M. 1954. Genetic homeostatis. Oliver and Boyd, London.

LEDIG, F. T., GURIES, R. R. AND BONEFELD, B. A. 1983. The relation of growth to heterozygosity in forest trees. Evol., $37,1227-1238$.

LFWONTIN, R. C. 1974. The genetic basis of evolutionary change. Columbia Univ. Press.

LEWONTIN, R. C., GINZBURG, L. R. AND TUJAPUKAR, S. D 1978. Heterozis as an explanation for large amounts of genetic polymorphism. Genetics, 88, 149-170.

LIVSHITS, G. AND KOBYLIANSKY, E. 1984a. Biochemical heterozygosity as a predictor of developmental homeostasis in man. Ann. Hum. Genet., 48, 173-184.

LIVSHITS, G. AND KOBYLIANSKY, E. 1984b. Comparative analysis of morphological traits in biochemically homozygous and heterozygous individuals from a single population. J. Hum. Evol., 13, 161-171.

LOKKI, J., SAURA, A., I.ANKINEN, P. AND SUOMALAINEN, F. 1976. Genetic polymorphism and evolution in panthenogenetic animals. VI. Diploid and triploid Polydrosus mollis (Coleoptera: Curculionidae). Hereditas, 82, 209-216.

LOKKI, J. ANI SAURA, A. 1980. Polyploidy in insect evolution. In W. H. Lewis (ed.) "Polyploidy. Biological Relevance". Plenum Press, New York and London, pp. 277-312.

LOUDENSLAGER, E. J. 1978. Variation in the genetic structure of Peromyscus populations. I. Genetic heterozygosity-its relationship to adaptive divergence. Bioch. Genet., 16, $1165-1179$.

MALINA, R. M. AND BUSCHAUNG, P. H. 1984. Anthropometric asymmetry in normal and mentally retarded males. Ann. Hum. Biol, 11, 515-531.

MAR(ERT, C L. AND URSPRUNG, H. 1971. Developmental genetics (Chapter, 8). Prentice-Hall Inc., New Jersey.

matsunaga, E. 1982. Perspective in mutation epidemiology. 1. Incidence and prevalence of genetic disease (excluding chromosomal aberrations) in human populations. Mutation Research, 99, 95-128.

MCANDREW, B. J., WARD, R. D. AND BEADMORE, J. A. 1982. Lack of relationship between morphological variance and enzyme heterozygosity in the place, Pleuronectus platessa. Heredity, 48, 117-125.

MCANDREW, B. J. AND MAJUMI)AR, K. C 1983. Tilapia stock identification using electrophoretic markers. Aquaculture, 30, 249-261.

MCKUSIC.K, V. A. 1983. Mendelian inheritance in Man. 6th ed The Johns Hopkins University Press. Baltimore, London.

MITTON, J. B. 1978. Relationship between heterozygosity for enzyme loci and variation of morphological characters in natural populations. Nature, 273, 661-662.

MITTON, J. AND PIERCE, 13. 1980. The distribution of individual heterozygosity in natural populations. Genetics, 95, 10431054.

MORAN, C. WILKINSON, P. ANI) SHAW, D. D. 1980. Allozyme variation across a narrow hybrid zone in the grasshopper, Caledia captiva. Heredity, 44, 69-81.

MORT()N. N. E. 1982. Outline of genetic epidemiology. Karger, Basel.

NEEL, J. V. 1958. A study of major congenital defects in Japanese infants. Am. J. Hum. Genet., 10, 398-445.

NEEL, J. V. 1980. Some considerations pertinent to monitoring human populations for changing mutation rates. Proceed- ings of the XIV International Congress of Genetics. Vol. 1, book 1, Mir Publishers, Moscow, pp 225-237.

NEI, M. 1984. Genetic polymorphism and neomutationism. In G. S. Mani (ed). "Evolutionary dynamics of genetic diversity". Lecture notes in biomathematic. 53, 214-241.

NEI, M. AND GiRAUR, D. 1984. Extent of protein polymorphism and neutral mutation theory. Evol. Biol, 17, 73-118.

NEI, M., MARUYAMA, T. ANI) CHAKRABORTY, R. 1975. The bottleneck effect and genetic variability in populations. Evol., 29, 1-10.

NEI, M. AND ROYCHOUDHURY, A. K. 1974. Genetic variation within and between three major human races of man, Caucasoids, Negroids and Mongoloids. Am. J. Hum. Genet., 26, 421-443.

NEVO, E. 1978. Genetic variation in natural populations: Patterns and theory. Theor. Pop. Biol., 13, 121-177.

NEVO, E. 1982. Genetic structure and differentiation during speciation in fossorial gerbil rodents. Mammalia, 46, 523530.

NEVO, E. $1983 a$. Population genetics and ecology: the interface. In D. S. Bendall (ed): "Evolution from molecules to men", Cambridge University Press. pp 287-321.

NEVO, E. $1983 \mathrm{~b}$. Adaptive significance of protein variation. In G. S. Oxford and D. Rollinson (eds): "Protein polymorphism: adaptive and taxonomic significance", Systematic Association Special Vol. N 24. Acad. Press, pp. 239-282.

NEVO, E., BEILES, A. AND BEN-SHLOMO, R. 1984. The evolutionary significance of genetic divesity: ecological, demographic and life history correlates. In G. S. Mani (ed): "Evolutionary dynamics of genetic diversity". Lecture notes in biomathematic, 53, 13-213.

NEVO, I: AND YANG, S. Y. 1982. Genetic diversity and ecological relationships of Marsh frog populations in Israel. Theor. Appl. Genet., 63, 317-330.

NEVO, E., ZOHARY, D., BROWN, A. H. D. AND HABER, M. 1979. Genetic diversity and environmental associations of wild barley, Hordenum spontaneum, in Israel. Evol., 33, 815-833.

NEVO, E., BAR-EL, CH., BAR, Z. AND BEILES, A. 1981. Genetic structure and climatic correlates of desert landsnails. Oecologia, 48, 199-208.

NIKITYUK, B. A. AND FILIPPOV, V. I. 1975. Anthropological trend in developmental genetics: heterosis as one of the factors of growth and development of children. Voprosi Anthropologii, 49, 24-50 (In Russian).

NYGREN, J. AND RASMUSON, M. 1980. Allozyme variation in natural populations of field vole (Microtus agrestis L.) Hereditas, 92, 65-72.

OHNO, S. 1970. Evolution by gene duplication. Springer-Verlag, Berlin.

PIERCE, B. A. AND MITTON, J. B. 1980. The relationship between genome size and genetic variation. Am. Natur., 116, 850861.

PItRC:E, B. A. AND MITTON, J. B. 1982. Allozyme heterozygosity and growth in tiger salamander, Ambystoma tigrinum. J. Heredity, 73, 250-253.

PRAVIMIN, I. F., ALTUKHOV, YU, P., DUC:HAREV, V. A., IYvotovsky, L. A. AND POLOzova, I. Y. 1982. Polymorphism of Pinus sylvestris populations at linked esterases loci, Dokladi Acad. Nauk of USSR, 262, 998-1000.

RYMAN, N., REUTERWALL, C., NYGREN, K. AND NYGREN, I. 1980. Genetic variation and differentiation in Scandinavian moose (Alces alces): are large mammal monomorphic? Evol., 34, 1037-1049.

RYMAN, N., CHAKRABORTY, R. AND NII, M. 1983. Differences in relative distribution of human gene diversity between electrophoretic and red and white cell antigen loci. Human Heredity, 33, 93-102. 
SAURA, A., LOKKI, J. AND SUOMALAINEN, E. 1977. Selection and genetic differentiation in parthenogenetic populations. In $\mathrm{S}$. Levin (ed) "Measuring selection in natural populations". Lecture Notes in Biomathematics, 19, 382-402.

SCHAAL, B. AND SMITH, W. 1980. The apportionment of genetic variation within and among populations of Desmodium nudiflorum. Evol., 34, 214-221.

SHAPIRO, B. L. 1970. Parental dental anomalies in mongolism: Comment on the basis and implications of variability. Ann. N.Y. Acad. Sci., 171, 562-577.

SINGH, S. M. AND ZOUROS, E. 1981. Genetics of growth rate in oysters and its implications for aquaculture. Can. J. Genet. Cytol., 23, 119-130.

SOFAER, J. A. 1979. Human toth-size asymmetry in cleft lip with or without cleft palate. Arch. Oval. Biol., 24, 141-146.

SOULE, M. E. 1976. Allozyme variation its determinants in space and time. In F. J. Ayala (ed) "Molecular evolution". Sunderland Publishers, Massachusetts.

SOULE, M. E. 1979. Heterozygosity and developmental stability: Another look. Evol., 33, 396-401.

SOULE, M. E. 1982. Allometric variation. 1. The theory and some consequences. Am. Natur., 120, 751-764.

SOULE, M. E. AND CUZIN-ROUDY, J. 1982. Allometric variation. 2. Developmental instability of extreme phenotypes. $A m$. Natur., 120, 765-786.

SMOUSE, P. E. AND LEDIG, F. T. 1984. Assessment of the fitness consequences of multiple-locus heterozygosity: the multiplicative overdominance model. (Submitted in publication).

TERRENATO, L. 1983. Natural selection associated with birth weight. IV. USA data from 1950-1976. Ann. Hum. Genet., $47,67-71$.
TERRENATO, L., GRAVIAN, M. F. AND ULIZZI, L. $1981 a$. Natural selection associated with birth weight. 1 . Selection intensity and selective deaths from birth to one month of life. Ann. Hum. Genet., 45, 55-63.

TERRENATO, L., GRAVINA, M. F. AND ULIZZI, L. 1981 b. Natural selection associated with birth weight. 3. Changes over the last twenty years. Ann. Hum. Genet., 45, 267-278.

TURELli, M. AND GINZBURG, L. R. 1983. Should individual fitness increase with heterozygosity? Genetics, 104, 191209.

ULIZZI, L., GRAVINA, M. F. AND TERRENATO, L. 1981. Natural selection associated with birth weight. 2. Stabilizing and directional components. Ann. Hum. Genet., 45, 207-212.

VRIJENHOEK, R. C. AND LERMAN, S. 1982. Heterozygosity and developmental stability under sexual and unsexual breeding systems. Evol, 36, 768-776.

VOGEL, F. 1984. Clinical consequences of heterozygosity for autosomal-recessive diseases. Clinical Genetics, 25, 381415 .

VUORINEN, J., HIMBERG, M. K. J. AND LANKINEN, P. 1981 Genetic differentiation in Coregous albula (L) (Salmonidae) populations in Finland Hereditas, 94, 113-121.

WARD, R. D. AND BEARDMORE, J. A. 1977. Protein variation in the plaice Pleuronectes platessa L. Genet. Res., 30, 45-62.

wOOLF, C. M. AND GIANAS, A. D. 1976. Congenital cleft lip and fluctuating dermatoglyphic asymmetry. Am. J. Hum Genet., 28, 400-403.

WOOLF, C. M. AND GIANAS, A. D. 1977. A study of fluctuating dermatoglyphic asymmetry in the sibs and parents of cleft lip propositi. Am. J. Hum. Genet., 29, 503-507.

WRIGHT, S. 1969. Evolution and the genetics of populations. Vol. 2. The theory of gene frequencies. The University of Chicago Press. Chicago. 